\title{
Manufacture of modified milk protein concentrate utilizing injection of carbon dioxide
}

\author{
Chenchaiah Marella, P. Salunke, A. C. Biswas, A. Kommineni, and L. E. Metzger ${ }^{1}$ \\ Midwest Dairy Foods Research Center, Department of Dairy Science, South Dakota State University, Brookings 57007-0647
}

\begin{abstract}
Dried milk protein concentrate is produced from skim milk using a combination of processes such as ultrafiltration (UF), evaporation or nanofiltration, and spray drying. It is well established that dried milk protein concentrate (MPC) that contains 80\% (MPC80) and greater protein content (relative to dry matter) can lose solubility during storage as a result of protein-protein interactions and formation of insoluble complexes. Previous studies have shown that partial replacement of calcium with sodium improves MPC80 functionality and prevents the loss in solubility during storage. Those studies have used $\mathrm{pH}$ adjustment with the addition of acids, addition of monovalent salts, or ion exchange treatment of UF retentate. The objective of this study was to use carbon dioxide to produce MPC80 with improved functionality. In this study, reduced-calcium MPC80 (RCMPC) was produced from skim milk that was subjected to injection of 2,200 ppm of $\mathrm{CO}_{2}$ before UF, along with additional $\mathrm{CO}_{2}$ injection at a flow rate of 1.5 to $2 \mathrm{~L} / \mathrm{min}$ during UF. A control MPC80 (CtrlMPC) was also produced from the same lot of skim milk without injection of $\mathrm{CO}_{2}$. The above processes were replicated 3 times, using different lots of skim milk for each replication. All the UF retentates were spray dried using a pilot-scale dryer. Skim milk and UF retentates were tested for $\zeta$-potential (net negative charge), particle size, and viscosity. All the MPC were stored at room $\left(22 \pm 1^{\circ} \mathrm{C}\right)$ and elevated $\left(40^{\circ} \mathrm{C}\right)$ temperatures for 6 mo. Solubility was measured by dissolving the dried $\mathrm{MPC}$ in water at $22^{\circ} \mathrm{C}$ and at $10^{\circ} \mathrm{C}$ (cold solubility). Injection of $\mathrm{CO}_{2}$ and the resultant solubilization of calcium phosphate had a significant effect on UF performance, resulting in 10 and $20 \%$ loss in initial and average flux, respectively. Processing of skim milk with injection of $\mathrm{CO}_{2}$ also resulted in higher irreversible fouling resistances. Compared with control, the reduced-calcium MPC had 28 and 34\% less ash
\end{abstract}

Received October 7, 2014

Accepted February 10, 2015.

${ }^{1}$ Corresponding author: Lloyd.Metzger@sdstate.edu and calcium, respectively. Injection of $\mathrm{CO}_{2}$ resulted in a significant decrease in $\zeta$-potential and a significant increase in the size of the casein micelle. Moreover, RCMPC had a significantly higher solubility after storage at room temperature and at elevated temperature. This study demonstrates that MPC80 with a reduced calcium and mineral content can be produced with injection of $\mathrm{CO}_{2}$ before and during UF of skim milk.

Key words: milk protein concentrate, carbon dioxide, ultrafiltration

\section{INTRODUCTION}

Ultrafiltration is a membrane separation technology that was introduced in dairy processing in the early 1970s. Ultrafiltration uses a semi-permeable membrane to fractionate components in milk based on their size (Huffman and Harper, 1999; Muthukumarappan and Marella, 2010). It has been extensively used by the dairy industry to produce a variety of dairy ingredients, including protein concentrates from cheese whey (Renner and Abd El-Salam, 1991; Marella, 2009) and milk (Jimenez-Flores and Kosikowski, 1986; Patel et al., 1991), fractionation of cheese whey proteins (Etzel and Chiu, 1997; Muller et al., 2003; Mehra and Kelley, 2004; Marella et al., 2011), and harvesting milk minerals from dairy co-product streams (Vyas and Tong, 2003; Mealy et al., 2013).

In production of milk protein concentrate with $80 \%$ protein (MPC80), skim milk is subjected to UF and diafiltration (DF). This process produces a liquid concentrate that is partially delactosed and high in protein. This liquid concentrate is further concentrated and spray dried to obtain MPC80 powder. During UF, water, lactose, NPN, and some soluble salts pass through the membrane and are collected in the permeate. Higher-molecular-weight constituents such as caseins, whey proteins, and some minerals are concentrated in the retentate stream (Jimenez-Flores and Kosikowski, 1986). The ratio of the volume of the milk to the volume of concentrate obtained during UF is known as volume reduction (VR). In a typical UF process, pasteurized skim milk is concentrated to a final volume of one-fifth to one-eighth of the volume of the original skim milk 
(VR of 5-8) to produce MPC that has 65 to $75 \%$ protein relative to total solids. For the production of MPC with higher protein content (protein content of $80 \%$ and above) relative to solids, DF is used in conjunction with the UF process. Diafiltration is the process of adding water to the product during UF and subsequent removal of it. Diafiltration removes additional lactose and soluble salts, thereby increasing the relative concentration of protein to total solids. As an example, in a typical manufacturing process, MPC with $80 \%$ protein relative to total solids is produced with a volume reduction of 5 with a DF level of 20 to $40 \%$ (based on volume of skim milk). This process produces a liquid MPC80 with 20 to $22 \%$ solids, and a protein:solids ratio of 80 . The liquid concentrate obtained is typically further concentrated by nanofiltration before it is spray dried.

Several researchers have conducted extensive studies on the solubility of commercially available MPC powders and have reported poor solubility for MPC80 powders after extended storage (de Castro-Morel and Harper, 2002; Sikand et al., 2011; Udabage et al., 2012). Poor solubility of MPC80 can lead to nugget formation during cheese making (Bhaskar et al., 2007), bar hardening in high-protein bars (Imtiaz et al., 2012), and settling of insoluble material when used in drink mixes (personal communications with MPC80 customers). Previous research has demonstrated that processing and storage conditions affect physicochemical interactions among the proteins, salts, and sugars, and can affect the solubility of MPC80. The physicochemical interactions that have been shown to affect the functional properties of MPCs include casein-casein and caseinwhey protein interactions (McKenna, 2000; Anema et al., 2006; Havea, 2006); hydrophobic association of casein micelles (Havea, 2006); formation of disulfidelinked $\beta-L G$ and casein complexes (Kameswaran and Smith, 1999; Anema et al., 2006); sulfhydryl-disulfide interchange reactions, and hydrophobic interactions among the proteins (Mao et al., 2012); lactosylation, deamidation, and protein cross-linking (Le et al., 2012); and formation of a thin crust of fused casein micelles on the surface of powder particles (Fyfe et al., 2011). Several of these studies have shown a strong correlation between solubility of MPC80 and their Ca content (Bhaskar et al., 2007; Sikand et al., 2011, 2013; Ye, 2011) and it is theorized that Ca present in MPC may be promoting protein-protein interactions during processing as well as storage.

To improve the functionality of MPC80, several researchers have developed new manufacturing processes that have focused on (1) application of physical treatments to the liquid concentrate before spray drying or to final dried MPC; or (2) process modifications that produce MPC with a modified mineral profile.
Banach et al. (2013) studied the effect of low- and high-shear extrusion and low-temperature toasting of MPC80 powders on the functional properties of the resultant modified MPC. Both of these treatments result in a decrease in solubility, hydrophobicity, and water-holding capacity. High-pressure homogenization (Augustin et al., 2012; Udabage et al., 2012), extrusionporosification (Bouvier et al., 2013), microfluidization, and ultrasonication (Augustin et al., 2012) of liquid concentrates before spray drying have been reported to improve the solubility of MPC. Partial disintegration of casein micelle due to these high shear treatments and the resultant high level of nonmicellar casein is thought to cause the improved solubility (Udabage et al., 2012). Mao et al. (2012) and Sikand et al. (2013) developed a novel process to produce mineral modified MPC80 utilizing DF with different levels of monovalent salts added to the DF water. The mineral modified MPC80 produced from this process exhibited modified functionality with higher solubility compared with conventionally produced MPC80. Dybing et al. (2007) and Bhaskar et al. (2007) used a cation-exchange process to replace divalent ions, especially calcium, and reported improved functional properties for the resultant calcium-depleted MPC.

The modified functionality resulting from partial demineralization of MPC may be a result of protein disaggregation that occurs when calcium phosphate is removed from the casein micelle. A new approach that may be applicable for production of partially demineralized MPC is the injection of $\mathrm{CO}_{2}$ before and during UF. Injection of $\mathrm{CO}_{2}$ into milk has been extensively studied, and it is widely used to increase the shelf life of raw milk (King and Mabbitt, 1982; Law and Mabbitt, 1983; Werner and Hotchkiss, 2006) and pasteurized milk (Ma and Barbano, 2003; Hotchkiss et al., 2006). Previous research has demonstrated that $\mathrm{CO}_{2}$ injection of cheese milk before rennet coagulation can be used to reduce the $\mathrm{pH}$ of milk and solubilize micellar calcium phosphate, which modifies the mineral profile of cheese produced from concentrated milk (Nelson et al., 2004). In a similar fashion, $\mathrm{CO}_{2}$ injection could be used to reduce the $\mathrm{pH}$ of milk and solubilize micellar calcium and phosphate before and during UF to produce MPC with reduced calcium and mineral content. Additionally, when $\mathrm{CO}_{2}$ is used as an acidulant, residual $\mathrm{CO}_{2}$ can easily be removed by heating or applying vacuum, whereas other acidulants such as organic acids cannot easily be removed.

The overall objective of this research was to use injection of $\mathrm{CO}_{2}$ before and during UF of skim milk and to determine the effect of $\mathrm{CO}_{2}$ injection on the mineral content, casein particle size, $\zeta$-potential, membrane performance, and solubility of MPC 80 . 
MATERIALS AND METHODS

\section{Experimental Design and Statistical Analysis}

As described below, preliminary laboratory-scale UF experiments were conducted to select the correct VR and DF levels for production of MPC 80. Additionally, preliminary pilot-scale experiments were conducted where pasteurized skim milk was injected with carbon dioxide to determine various levels of dissolved $\mathrm{CO}_{2}$. From these preliminary experiments, the required level of $\mathrm{CO}_{2}$ injection before and during UF was selected for replicated analysis in a pilot scale study. In this study, 3 different lots of skim milk were injected with 2,200 ppm of dissolved $\mathrm{CO}_{2}$ before UF, along with additional injections of $\mathrm{CO}_{2}$ during UF. A portion of each lot of skim milk was also used to produce MPC80 without $\mathrm{CO}_{2}$ injection. The UF retentates were spray dried using a pilot-scale Niro dryer (Niro dryer model 1, Niro Inc., Columbia, MD) fitted with a centrifugal disc atomizer. All powders were evaluated for cold-water solubility, solubility after room temperature, and elevated temperature storage. A schematic of experimental design and the sample codes is shown in Figure 1.

\section{Laboratory-Scale Experiments}

Preliminary laboratory-scale experiments were conducted using a plate-and-frame unit (Marella et al., 2011). These experiments were conducted to select the required VR and level of DF needed to produce MPC80. In each test, $1,500 \mathrm{~mL}$ of pasteurized $\left(63^{\circ} \mathrm{C} / 30\right.$

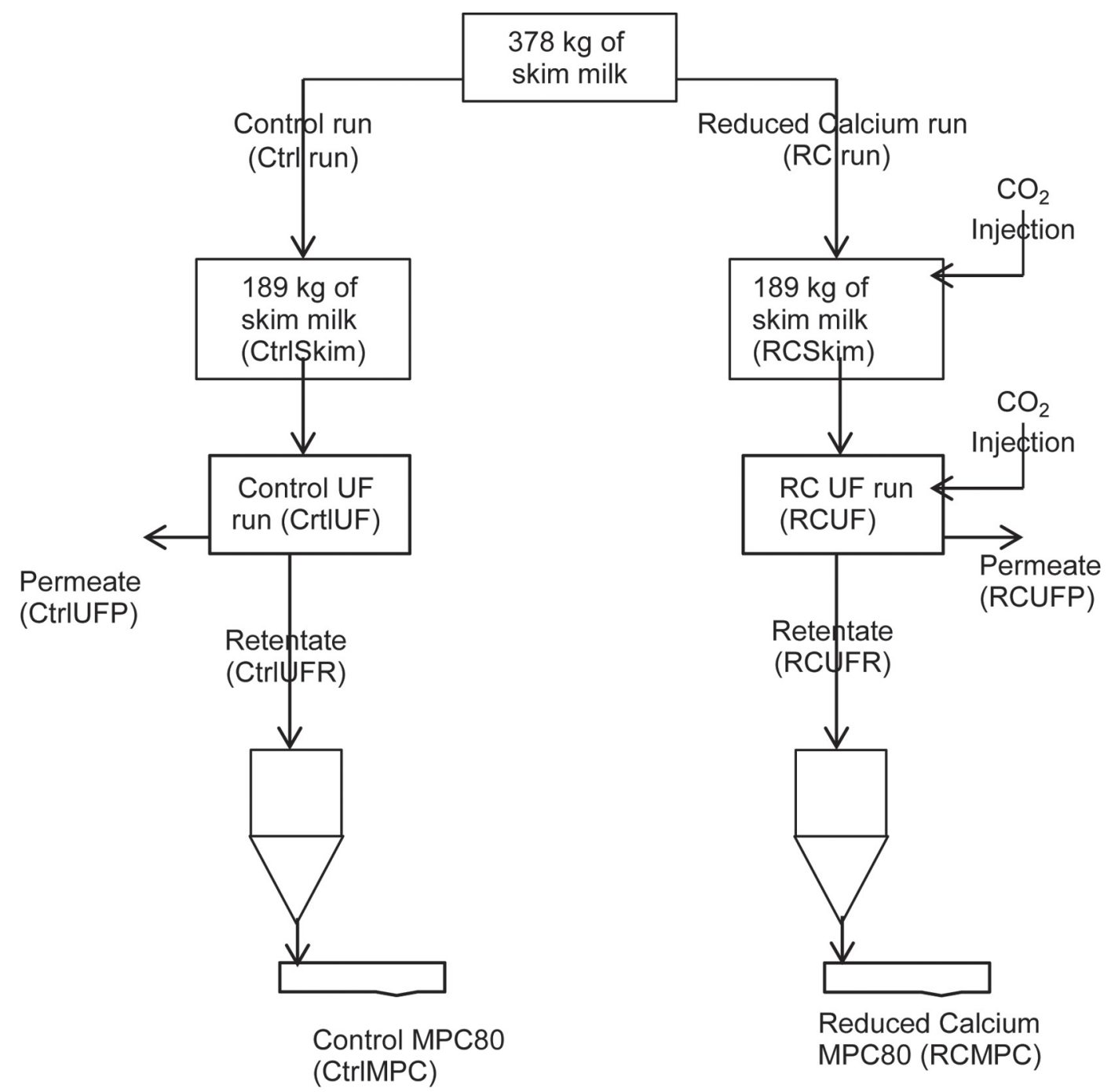

Figure 1. Flow diagram of experimental design and sample codes (in parentheses). Both control (Ctrl) and reduced-calcium (RC) runs were repeated 3 times using different lots of skim milk. Skim = skim milk; UF = ultrafiltered milk; $\mathrm{P}=$ permeate; $\mathrm{R}=$ retentate; $\mathrm{MPC} 80=$ milk protein concentrate with $80 \%$ protein. 


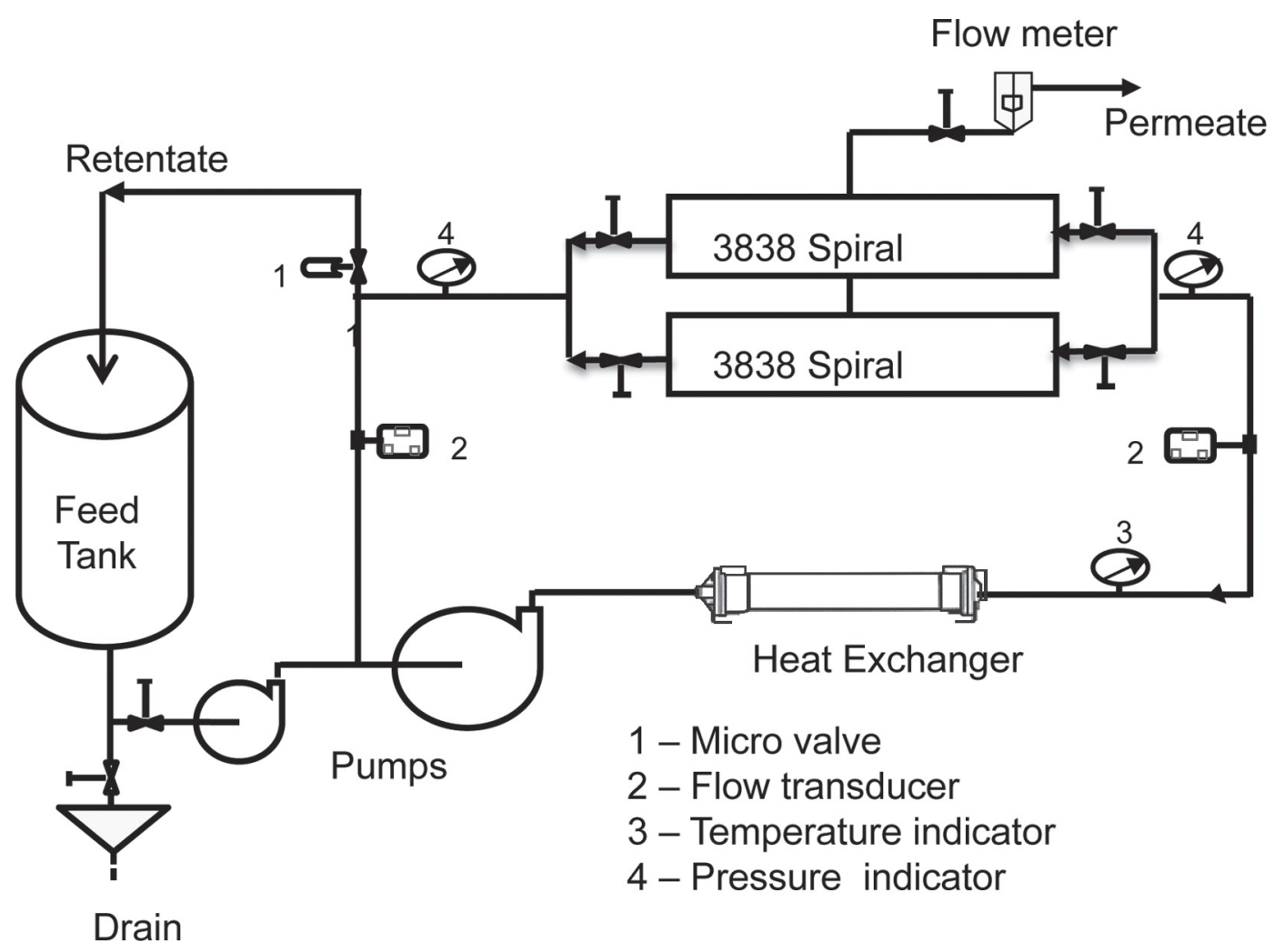

Figure 2. Schematic of pilot UF unit, which houses 2 spiral-wound elements (in 3838 format $-965 \mathrm{~mm}$ long and $96.5 \mathrm{~mm}$ in diameter) in parallel.

min) skim milk was concentrated to VR of 4 to 8 in a continuous concentration mode. A polyethersulfone membrane (Parker process advanced filtration division, Parker Hannifin Corp., Oxnard, CA) with a molecular weight cut-off of $10 \mathrm{kDa}$ in flat sheet configuration was used. The UF process was conducted at $15^{\circ} \mathrm{C}$ with a transmembrane pressure (TMP) of $207 \mathrm{kPa}(30 \mathrm{psi})$. During these experiments, DF water from 0 to $50 \%$ (based on the feed volume) was added. Samples of skim milk and retentates were analyzed for TS and protein using standard methods of analysis (Hooi et al., 2004).

\section{Pilot-Scale Experiments}

Pilot-scale experiments were conducted using the pilot UF unit shown in Figure 2. Two 10-kDa polyethersulfone membranes (Parker Hannifin Corp.) were used in parallel. Each membrane element was $97 \mathrm{~mm}$ in diameter and $965 \mathrm{~mm}$ in length with a 1.1-mm feed spacer and a total surface area of $5.7 \mathrm{~m}^{2}$ per element. The inlet and outlet pressures to the membrane element were 345 and $207 \mathrm{kPa}$, respectively, resulting in a TMP of $276 \mathrm{kPa}$. All experiments were conducted at $15^{\circ} \mathrm{C}$. Each experiment began with $189 \mathrm{~kg}$ of pasteurized skim milk. The feed was concentrated to a final retentate of $37.85 \mathrm{~kg}$, resulting in a VR of 5 . To control the viscosity of the retentate and to remove soluble solutes, during the process, DF water $(10 \%$ of the starting feed volume) was added at VR of $2,2.5,3$, and 4 , for a total DF of $40 \%$ of the feed volume.

Before UF, pasteurized skim milk was injected with $\mathrm{CO}_{2}$ to obtain a dissolved $\mathrm{CO}_{2}$ of $2,200 \mathrm{ppm}$ in the skim milk. The $\mathrm{CO}_{2}$ injection conditions are described below. After $\mathrm{CO}_{2}$ injection, the skim milk was held for $1 \mathrm{~h}$ for equilibration. At the end of equilibration, the skim milk was warmed to $15^{\circ} \mathrm{C}$ and processed in the UF unit. At the end of the UF process, samples of permeate and retentate were collected for wet chemistry and measurement of dissolved $\mathrm{CO}_{2}$. All of the retentate was collected for further drying to produce powder.

\section{$\mathrm{CO}_{2}$ Injection}

A stainless steel sparger cup $(12.7 \times 9.5 \times 25.4 \mathrm{~mm})$ with $10-\mu \mathrm{m}$ porosity was used to inject $\mathrm{CO}_{2}$ into the skim milk. For injection of $\mathrm{CO}_{2}$, the balance tank of the UF unit was filled with skim milk, membrane housings were isolated, and the feed pump was used to recirculate the skim milk through the piping of the UF unit (Figure 2). Backpressure of $138 \mathrm{kPa}$ was applied dur- 
ing recirculation. The $\mathrm{CO}_{2}$ pressure was maintained at $527.1 \mathrm{kPa}$ at the inlet to the sparger. The $\mathrm{CO}_{2}$ flow rate was maintained at $14.1 \mathrm{~L} / \mathrm{min}$ and the skim milk flow was at 57 to $68 \mathrm{~L} / \mathrm{min}$. During the sparging and the $1-\mathrm{h}$ equilibration, the temperature of skim milk was maintained at 4 to $5^{\circ} \mathrm{C}$ using the inline heat exchanger in the UF unit. The initial $\mathrm{pH}$ of skim milk was 6.62 , and after $30 \mathrm{~min}$, the $\mathrm{pH}$ decreased to 5.71. At this point, $\mathrm{CO}_{2}$ injection was stopped, and the milk was held for 60 min. Subsequently, the skim milk was warmed to $15^{\circ} \mathrm{C}$ and UF processing was started. During UF, the $\mathrm{pH}$ of the skim milk was continuously recorded and maintained at 5.8 with additional injection of $\mathrm{CO}_{2}$ (at a flow rate of 1.5 to $2 \mathrm{~L} / \mathrm{min}$ ).

\section{Measurement of Dissolved $\mathrm{CO}_{2}$}

Dissolved $\mathrm{CO}_{2}$ was measured using an enzymatic assay. This assay used a $\mathrm{CO}_{2}$ (liquid) reagent kit (Cat. No. C7502-120) and a test method (manual method test: $\mathrm{CO}_{2} 405$, Cat. No. C7502) supplied by Pointe Scientific Inc. (Canton, MI). The reagent kit and test method were originally intended for quantitative determination of $\mathrm{CO}_{2}$ in blood serum, and the method is based on the principle that $\mathrm{CO}_{2}$ (in the form of bicarbonate ions) reacts with phosphoenolpyruvate (PEP), in the presence of phosphoenolpyruvate carboxylase (PEPC) and forms oxaloacetate. Oxaloacetate oxidizes NADH in the presence of malate dehydrogenase, thereby decreasing the absorbance monitored between 405 and $415 \mathrm{~nm}$. The decrease is proportional to the amount of $\mathrm{CO}_{2}$ present in the sample:

$\mathrm{PEP}+\mathrm{HCO}_{3}^{-} \stackrel{\mathrm{PEPC}+\mathrm{Mg}^{2+}}{\longrightarrow}$ Oxaloacetate $+\mathrm{H}_{2} \mathrm{PO}_{4}^{-}$
Oxaloacetate $+\mathrm{NADH}+\mathrm{H}^{+} \stackrel{\mathrm{MDH}}{\longrightarrow}$ Malate $+\mathrm{NAD}^{+}$.

This enzymatic method can be used for measuring $\mathrm{CO}_{2}$ present as $\mathrm{HCO}_{3}^{-}, \mathrm{CO}_{3}^{2-}$, and dissolved gas. Dissolved $\mathrm{CO}_{2}$ present in skim milk, permeate, or retentate samples was trapped as $\mathrm{Na}_{2} \mathrm{CO}_{3}$ using $4 M \mathrm{NaOH}$ (Crow and Martley, 1991).

To measure the dissolved $\mathrm{CO}_{2}$, approximately $0.5 \mathrm{~g}$ of sample (skim milk/permeate/retentate) was weighed into a 2-mL centrifuge vial that was previously flushed with $\mathrm{N}_{2}$ gas. Then, $0.5 \mathrm{~mL}$ of boiled water and $60 \mu \mathrm{L}$ of $4 M \mathrm{NaOH}$ were added to the sample. After determining the final weight, the sample was mixed by vortexing followed by centrifugation of the vial at $17,091 \times g$ at $20^{\circ} \mathrm{C}$ for $10 \mathrm{~min}$. Any fat layer present was removed with a spatula. The UV-visible spectrophotometer was set at a wavelength of $405 \mathrm{~nm}$ and was zeroed with distilled water. A 1-mL sample of $\mathrm{CO}_{2}$ reagent (PEP and PEPC) was added to a disposable cuvette flushed with $\mathrm{N}_{2}$ gas. The cuvette was then incubated at $37^{\circ} \mathrm{C}$ for $5 \mathrm{~min}$. This incubation activates the enzyme present in the $\mathrm{CO}_{2}$ reagent sample. At the end of incubation, $10 \mu \mathrm{L}$ of the prepared sample was added to the cuvette and the contents were mixed by inverting 4 or 5 times. Absorbance was measured $30 \mathrm{~s}$ after adding the sample (A1); then, the cuvette was held in a water bath at $37^{\circ} \mathrm{C}$ for 6 min and a second reading (A2) was taken. Dissolved $\mathrm{CO}_{2}$ (ppm) was calculated as follows:

$$
\frac{(\mathrm{A} 1-\mathrm{A} 2) \text { Sample }}{(\mathrm{A} 1-\mathrm{A} 2) \text { Standard }} \times[\text { standard }, \mathrm{ppm}] \times \text { dilution factor. }
$$

\section{Spray Drying}

The UF retentates were spray dried using a singlestage pilot-scale dryer fitted with a Niro centrifugal disc atomizer (ASO 412E, Niro Inc., Columbia, MD). The inlet and outlet temperatures were maintained at 200 and $90^{\circ} \mathrm{C}$, respectively. The powders were collected and packed in airtight containers and stored refrigerated $\left(4^{\circ} \mathrm{C}\right)$ until further analysis was completed.

\section{Chemical Analysis}

The skim milk, retentate, and permeate samples from MPC manufacture were collected and immediately cooled to $4^{\circ} \mathrm{C}$. The TS, total fat, and ash of each sample was determined using standard wet chemistry procedures as described by Hooi et al. (2004). The pH of all the samples was measured in duplicate with a $\mathrm{pH}$ meter (pH meter 340, Corning Inc., Corning, NY) equipped with an Accumet gel-filled glass electrode with a spear tip (Fisher Scientific, Fair Lawn, NJ). Lactose was measured using an HPLC-based method, as described by Amamcharla and Metzger (2011) for milk except that a sample size of $1 \mathrm{~g}$ was used. Mineral analysis of the samples was done using inductively coupled plasmaoptical emission spectroscopy.

\section{Ultrafiltration Processing Data}

The average flux and TMP were determined as follows: average flux is the permeate flow rate through the membrane and is expressed in liters per $\mathrm{m}^{2}$ and hour $\left(\mathrm{L} / \mathrm{m}^{2} \cdot \mathrm{h}\right)$ :

$$
\text { Average flux }=\frac{\text { Permeate flow }(\mathrm{L})}{\text { Area of membrane }\left(\mathrm{m}^{2}\right) \times \text { time }(\mathrm{h})} .
$$

Transmembrane pressure is the driving force for the membrane separation and is determined by subtracting 
the permeate pressure $\left(\mathrm{P}_{\mathrm{p}}\right)$ from the average of the inlet $\left(\mathrm{P}_{\text {in }}\right)$ and outlet $\left(\mathrm{P}_{\text {out }}\right)$ pressures:

$$
\mathrm{TMP}=\frac{\mathrm{P}_{\text {in }}+\mathrm{P}_{\text {out }}}{2}-\mathrm{P}_{\mathrm{p}} .
$$

Because permeate was collected at atmospheric pressure, its pressure was considered to be zero.

\section{Resistances}

In any membrane process, the mass flow through the membrane is expressed as flux, and it is a function of the driving force, resistance, and viscosity of the permeate. The mass flow is directly proportional to the driving force and indirectly proportional to the resistance $(\mathrm{R})$ and viscosity $\left(\mu_{\mathrm{p}}\right)$ of the permeate:

$$
\text { Mass flow (flux) }=\frac{T M P}{\mathrm{R} \times \mu_{\mathrm{p}}} \text {. }
$$

The clean water flux and flux during processing were used to calculate membrane resistance (MR) and resistance during processing (RDP) as follows:

$$
\begin{gathered}
\mathrm{MR}=\frac{\mathrm{TMP}}{\text { Clean water flux } \times \mu_{\mathrm{p}}}, \\
\mathrm{RDP}=\frac{\mathrm{TMP}}{\text { Process flux } \times \mu_{\mathrm{p}}} .
\end{gathered}
$$

The difference between RDP and MR is the overall fouling resistance, Rfo. A small Rfo indicates improved permeate rates through the membrane: $\mathrm{Rfo}=\mathrm{RDP}-$ MR.

At the end of the process when the membrane was rinsed with water all the loosely adhered material on the membrane was removed. The water flux taken after rinsing is used to determine the resistance after processing and rinsing (RAPR):

$$
\mathrm{RAPR}=\frac{\mathrm{TMP}}{\text { Final water flux } \times \mu_{\mathrm{p}}} .
$$

The difference between RAPR and MR is the irreversible fouling resistance, $\mathrm{Rfi}$, where $\mathrm{Rfi}=\mathrm{RAPR}$ - MR.

\section{Viscosity}

The viscosity of UF concentrates ( $17 \%$ solids) was measured at $20^{\circ} \mathrm{C}$ with a Viscoanalyzer (Reologica
Instruments AB, ATS Rheosystems, Rheometric Scientific Inc., Piscataway, NJ) using bob-and-cup geometry. The samples were conditioned at $20^{\circ} \mathrm{C}$ for $60 \mathrm{~s}$ before analysis. About $16 \mathrm{~mL}$ of each concentrate at $20^{\circ} \mathrm{C}$ was transferred into the cup of the rheometer, and the bob was lowered until the whole bob surface was covered. An equilibrium time of $25.0 \mathrm{~s}$ and a pre-shear rate of 10 $\mathrm{s}^{-1}$ for $20.0 \mathrm{~s}$ was applied. The viscosity of the solution was measured at a shear rate of $1.000 \mathrm{E}+0-2.50 \mathrm{E}+2$ per $\mathrm{s}$ with a delay time of $1.032 \mathrm{E}+0-2.000 \mathrm{E}+0 \mathrm{~s}$. The viscosity was reported at a shear rate of $100 \mathrm{~s}^{-1}$.

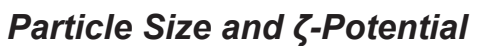

The particle size of casein micelles in the starting skim milk and UF retentates was measured by dynamic light scattering using a Zetasizer Nano-ZS (with $633 \mathrm{~nm}$ He-Ne laser; Malvern Instruments Ltd., Malvern, UK). Skim milk and UF retentates were diluted 1:100 with corresponding UF permeates. Control skim milk (CtrlSkim) and control UF retentate (CtrlUFR) were diluted with control UF permeate (CtrlUFP) obtained from control runs. The diluted Ctrl samples had a $\mathrm{pH}$ of 6.82. Skim milk used for reduced-calcium (RC) skim and reduced-calcium UF retentate (RCUFR) were diluted with reduced calcium permeate (RCUFP) obtained from $\mathrm{RC}$ runs. The diluted $\mathrm{RC}$ samples had a $\mathrm{pH}$ of 6.02. Before measuring the $\zeta$-potential (i.e., net negative charge), all diluted samples were filtered through $0.45-\mu \mathrm{m}$ syringe filters. The electrophoretic mobilities, and hence the calculated $\zeta$-potential of casein micelles, were measured at constant temperature of $25^{\circ} \mathrm{C}$. The measurement interval was set to -50 to $+10 \mathrm{mV}$.

\section{Solubility in Water at Room Temperature}

Five percent protein solutions (wt/wt) were made by dissolving milk protein concentrate powders in distilled water at $22 \pm 1^{\circ} \mathrm{C}$. The solutions were stirred for $30 \mathrm{~min}$ using a magnetic stirrer and a stir plate (Fisher Scientific). The stirring speed was maintained at $300 \mathrm{rpm}$. After stirring, each solution was hydrated overnight at $4^{\circ} \mathrm{C}$. After overnight hydration, the protein solution was again stirred for $30 \mathrm{~min}$ at $300 \mathrm{rpm}$. The $\mathrm{pH}$ of the protein solutions was adjusted to approximately $\mathrm{pH} 7.0$ using $2.0 \mathrm{~N} \mathrm{NaOH}$, and then fine $\mathrm{pH}$ adjustment was made using $0.2 \mathrm{~N} \mathrm{NaOH}$. After $1 \mathrm{~h}$ of equilibration, the solubility method described by Havea (2006) was used with some modifications. Aliquots of each reconstituted MPC (50 mL) were centrifuged (CR4-12, Jouan Inc., Riviera Beach, FL) at $700 \times g$ for $10 \mathrm{~min}$. The $5 \%$ protein solution (before centrifugation) and the supernatant (after centrifugation) were analyzed for TS. The TS was determined by forced draft oven (Fisher 
Table 1. Protein levels in milk protein concentrates as a function of volume reduction (VR) and diafiltration $(\mathrm{DF})^{1}$

\begin{tabular}{llllll}
\hline Run no. & VR & DF & TS & Protein & Protein:TS \\
\hline 1 & 4 & 20 & 16.72 & 11.75 & 70.3 \\
2 & 4 & 30 & 16.77 & 12.14 & 72.4 \\
3 & 5 & 0 & 20.73 & 13.34 & 64.4 \\
3 & 7 & 0 & 23.07 & 16.48 & 71.4 \\
3 & 8 & 0 & 27.48 & 20.58 & 74.9 \\
4 & 5 & 30 & 18.56 & 14.55 & 78.4 \\
5 & 5 & 40 & 17.84 & 14.40 & 80.7 \\
6 & 6 & 50 & 14.26 & 11.95 & 83.8 \\
\hline
\end{tabular}

${ }^{1}$ All data were means of 2 runs.

Scientific) drying at $100^{\circ} \mathrm{C}$ for $4 \mathrm{~h}$. The solubility was calculated as the TS of the supernatant, expressed as percentage of the TS of the $5 \%$ protein solution before centrifugation.

\section{Solubility in Cold Water}

Cold-water solubility was measured by dissolving MPC80 powders in cold tap water $\left(\right.$ at $\left.10^{\circ} \mathrm{C}\right)$. To simulate the use of MPC80 in drink mixes, powders were dissolved in cold water by high-speed stirring (at 900 $\mathrm{rpm}$ ) for $2 \mathrm{~min}$. The initial mean $\mathrm{pH}$ of the $5 \%$ protein solutions was 6.33 and 6.96 , respectively, for the RC and Ctrl treatments. Before measuring solubility, the $\mathrm{pH}$ of each $5 \%$ protein solution was adjusted close to $\mathrm{pH} 7.0$ using $2.0 \mathrm{~N} \mathrm{NaOH}$ and then fine $\mathrm{pH}$ adjustment were made using $0.2 \mathrm{~N} \mathrm{NaOH}$. After $\mathrm{pH}$ adjustment, the samples were allowed to equilibrate for $1 \mathrm{~h}$, and solubility was measured as described previously for room temperature.

\section{Statistical Analysis}

All data were analyzed by MIXED procedure in SAS (SAS Institute Inc., Cary, NC) with a Type I error rate $(\alpha)$ of 0.05 to test for significant differences among the treatments.

\section{RESULTS AND DISCUSSION}

\section{Effect of VR and DF Level on Protein:TS Ratio in MPC}

Data obtained from laboratory-scale UF experiments conducted to determine the effect of VR and DF level on protein:TS ratio in MPC are shown in Table 1. Milk protein concentrate powders with a particular protein:TS ratio can be obtained by using a range of VR ratios and DF levels. In the present study, we selected a VR of 5 and DF level of $40 \%$ for production of MPC80.

\section{Effect of $\mathrm{CO}_{2}$ Injection on Ash and Calcium Contents of MPC}

Average composition of UF retentates, permeates, and MPC powders manufactured in the study is shown in Table 2. Total solids, fat, protein, NPN, lactose, and protein:TS ratio did not differ $(P>0.05)$ for RCMPC and CtrlMPC. However, ash and $\mathrm{Ca}$ contents were significantly different $(P<0.05)$ for RCMPC and CtrlMPC powders. Similar results were observed for UF retentates and permeates. As seen from the ash and $\mathrm{Ca}$ contents of MPC powders, the ash content of RCMPC was $28 \%$ lower and Ca content was $33 \%$ lower as compared with the control. The reductions in ash and $\mathrm{Ca}$ contents were due to solubilization of calcium phosphate associated with casein micelles because of the reduced pH (Van Hooydonk et al., 1986; Dalgleish and Law, 1989; Law and Leaver, 1998), which passed into the permeate during the UF-DF process used in production of MPC. The mean dissolved $\mathrm{CO}_{2}$ levels in skim milk, UF retentate, permeate, and $5 \%$ protein solutions of MPC powders are shown in Table 3. The skim milk used in the control MPC had $171 \mathrm{ppm}$ of dissolved $\mathrm{CO}_{2}$, whereas the $\mathrm{CO}_{2}$-injected skim milk had 2,137 ppm of dissolved $\mathrm{CO}_{2}$. The dissolved $\mathrm{CO}_{2}$ in the RCUF retentate and permeate was 782 and 1,263 ppm, respectively, whereas the dissolved $\mathrm{CO}_{2}$ in the CtrlUF retentate and permeate was 106 and $102 \mathrm{ppm}$, respectively. These dissolved $\mathrm{CO}_{2}$ levels for $\mathrm{RC}$ and Ctrl treatments were different $(P<0.05)$ for the milk, retentate, and permeate. The $\mathrm{pH}$ values of the $\mathrm{RC}$ and Ctrl feeds, UF retentates, and UF permeates were also significantly different $(P<0.05)$ for treatment and control samples. The $\mathrm{pH}$ of the reconstituted $5 \%$ protein solutions of RCMPC and CtrlMPC were significantly different $(P<0.05)$, whereas the dissolved $\mathrm{CO}_{2}$ levels were not different $(P>0.05)$. Because there was no difference in the level of dissolved $\mathrm{CO}_{2}$, the lower $\mathrm{pH}$ of the RCMPC solution was probably a result of the lower mineral content of this sample. These results also 
Table 2. Mean composition ( $\%, \mathrm{n}=3$; SD in parentheses) of UF retentates, permeates, and milk protein concentrate (MPC) powders obtained in the study

\begin{tabular}{|c|c|c|c|c|c|c|c|c|}
\hline Sample $^{1}$ & $\mathrm{TS}$ & Fat & Protein & $\mathrm{NPN}$ & Ash & Lactose & $\mathrm{Ca}$ & Protein:TS \\
\hline \multicolumn{9}{|c|}{ UF retentates } \\
\hline RCUF & $18.10^{\mathrm{a}}$ & $0.48^{\mathrm{a}}$ & $14.59^{\mathrm{a}}$ & $0.12^{\mathrm{a}}$ & $0.93^{\mathrm{b}}$ & $1.88^{\mathrm{a}}$ & $0.257^{\mathrm{b}}$ & $80.6^{\mathrm{a}}$ \\
\hline CtrlUF & $(0.31)$ & $(0.02)$ & $(0.30)$ & $(0.03)$ & $(0.04)$ & $(0.08)$ & $(0.03)$ & $(0.92)$ \\
\hline \multicolumn{9}{|c|}{ UF permeates } \\
\hline RCUF & $4.34^{\mathrm{a}}$ & $\mathrm{ND}^{2}$ & $0.14^{\mathrm{a}}$ & $0.14^{\mathrm{a}}$ & $0.43^{\mathrm{a}}$ & $3.8^{\mathrm{a}}$ & $0.057^{\mathrm{a}}$ & $3.23^{\mathrm{a}}$ \\
\hline CtrlUF & $(0.09)$ & & $(0.01)$ & $(0.01)$ & $(0.01)$ & $(0.05)$ & $(0.00)$ & $(0.13)$ \\
\hline \multicolumn{9}{|l|}{ Powders } \\
\hline \multirow[t]{2}{*}{ RCMPC } & $95.92^{\mathrm{a}}$ & $2.51^{\mathrm{a}}$ & $77.51^{\mathrm{a}}$ & $1.35^{\mathrm{a}}$ & $4.96^{\mathrm{b}}$ & $10.53^{\mathrm{a}}$ & $1.319^{\mathrm{b}}$ & $80.86^{\mathrm{a}}$ \\
\hline & $(0.59)$ & $(0.19)$ & $(0.07)$ & $(0.11)$ & $(0.05)$ & $(0.37)$ & $(0.04)$ & $(0.45)$ \\
\hline \multirow[t]{2}{*}{ CtrlMPC } & $95.86^{\mathrm{a}}$ & $2.51^{\mathrm{a}}$ & $76.98^{\mathrm{a}}$ & $1.28^{\mathrm{a}}$ & $6.94^{\mathrm{a}}$ & $9.89^{\mathrm{a}}$ & $2.00^{\mathrm{a}}$ & $80.03^{\mathrm{a}}$ \\
\hline & $(0.58)$ & $(0.14)$ & $(0.48)$ & $(0.13)$ & $(0.10)$ & $(0.51)$ & $(0.05)$ & $(0.21)$ \\
\hline
\end{tabular}

${ }^{\mathrm{a}, \mathrm{b}}$ Values with the same superscript within UF retentates, UF permeates, and powders are not statistically different $(P>0.05)$.

${ }^{1} \mathrm{RCUF}$ and CtrlUF $=$ reduced-calcium and control UF runs, respectively; RCMPC and CtrlMPC $=$ reduced-calcium and control MPC runs, respectively.

${ }^{2} \mathrm{ND}=$ not determined

indicate that the dissolved $\mathrm{CO}_{2}$ in the RCUF retentate was removed during the drying process.

\section{Effect of $\mathrm{CO}_{2}$ Injection on $\zeta$-Potential and Particle Size of Casein Micelles}

Data on $\zeta$-potential of casein micelle in skim milk and UF retentates is presented in Table 4 . We detected a significant difference $(P<0.05)$ in the $\zeta$-potential of control skim milk (CtrlSkim) and $\mathrm{CO}_{2}$ injected skim milk (RCSkim). Whereas the CtrlSkim had a $\zeta$-potential of $-11.34 \mathrm{mV}$, the RCSkim had a $\zeta$-potential of -8.06 $\mathrm{mV}$. Injection of $\mathrm{CO}_{2}$ with the consequent reduction in $\mathrm{pH}$ and solubilization of calcium phosphate resulted in a decrease in the $\zeta$-potential of the casein micelles. The $\zeta$-potential is a measure of the net negative charge that casein micelles carry due to the presence of glycosylated residues of $\kappa$-casein. Cations present in the serum phase can interact with these negative charges, shielding the charges on the micelle (Baudry et al., 2005; Huppertz and Fox, 2006; Ahmad et al., 2008). The $\zeta$-potentials of CtrlUFR and RCUFR were also $(P<0.05)$ different.
When compared with the feed (skim milk) used for the UF runs, the UF retentates had a significantly higher $\zeta$-potential. The DF step used in the process of UF removes soluble minerals. This partial removal of soluble divalent calcium might have contributed to an increase in net negative charge on the casein micelle.

The data on particle size of casein micelles in skim milk and UF retentates are shown in Table 4. Significant $(P<0.05)$ differences were found in the average size of casein micelles in CtrlSkim, CtrlUFR, RCSkim, and RCUFR. In the present study, we detected an approximately $14 \%$ increase in the size of casein micelles as a result of the VR (5) and DF (40\%) used during UF in the control (CtrlSkim vs. CtrlUFR). Injection of $\mathrm{CO}_{2}$ resulted in swelling of the casein micelle and, for both RCSkim and RCUFR, a size increase of approximately $23 \%$ compared with the size of the casein micelles in skim milk. Previous research (Helen et al., 2010) also reported an increase in casein micelle diameter as a result of calcium removal. The mineral profile of the solution in which casein micelles are dispersed influences the organization of the micelle and its size (Ahmad et al.,

Table 3. Dissolved $\mathrm{CO}_{2}$ levels and $\mathrm{pH}$ values $(\mathrm{n}=3$; $\mathrm{SD}$ in parentheses) in feed, UF retentate, UF permeate, and $5 \%$ protein solutions

\begin{tabular}{|c|c|c|c|c|c|c|c|c|}
\hline \multirow[b]{2}{*}{ Item } & \multicolumn{2}{|c|}{ Feed } & \multicolumn{2}{|c|}{ UF retentate } & \multicolumn{2}{|c|}{ UF permeate } & \multicolumn{2}{|c|}{$5 \%$ protein } \\
\hline & $\mathrm{CO}_{2}, \mathrm{ppm}$ & $\mathrm{pH}$ & $\mathrm{CO}_{2}, \mathrm{ppm}$ & $\mathrm{pH}$ & $\mathrm{CO}_{2}, \mathrm{ppm}$ & $\mathrm{pH}$ & $\mathrm{CO}_{2}, \mathrm{ppm}$ & $\mathrm{pH}$ \\
\hline $\mathrm{RC}$ run & $2,137^{\mathrm{a}}$ & $5.71^{\mathrm{b}}$ & $782^{\mathrm{a}}$ & $5.81^{\mathrm{b}}$ & $1,263^{\mathrm{a}}$ & $6.02^{\mathrm{b}}$ & $132^{\mathrm{a}}$ & $6.33^{\mathrm{a}}$ \\
\hline Ctrl run & $\begin{array}{l}(59.09) \\
171^{\mathrm{b}} \\
(20.81)\end{array}$ & $\begin{array}{r}(0.02) \\
6.75^{\mathrm{a}} \\
(0.06)\end{array}$ & $\begin{array}{l}(76.05) \\
106^{\mathrm{b}} \\
(10.39)\end{array}$ & $\begin{array}{r}(0.05) \\
6.84^{\mathrm{a}} \\
(0.06)\end{array}$ & $\begin{array}{l}(126) \\
102^{b} \\
(3.46)\end{array}$ & $\begin{array}{r}(0.05) \\
6.82^{\mathrm{a}} \\
(0.03)\end{array}$ & $\begin{array}{c}(21.55) \\
104^{\mathrm{a}} \\
(3.00)\end{array}$ & $\begin{array}{r}(0.02) \\
6.96^{5} \\
(0.05)\end{array}$ \\
\hline
\end{tabular}

\footnotetext{
${ }^{\mathrm{a}, \mathrm{b}}$ Values with same superscripts within a column are not statistically different $(P>0.05)$.

${ }^{1} \mathrm{RC}$ run and $\mathrm{Ctrl}$ run = reduced-calcium and control $80 \%$ milk protein concentrate runs, respectively.
} 
Table 4. Mean $\zeta$-potential (net negative charge) and size $(\mathrm{nm})$ of casein micelles $(\mathrm{n}=3$; SD in parentheses) for skim milk and UF retentates ${ }^{1}$

\begin{tabular}{lcccc}
\hline & CtrlSkim & RCSkim & CtrlUFR & RCUFR \\
Item & $(\mathrm{pH}=6.82)$ & $(\mathrm{pH}=6.02)$ & $(\mathrm{pH}=6.82)$ & $(\mathrm{pH}=6.02)$ \\
\hline S-Potential & $-11.34^{\mathrm{b}}$ & $-8.06^{\mathrm{a}}$ & $-14.07^{\mathrm{c}}$ & $-10.84^{\mathrm{b}}$ \\
\multirow{2}{*}{ Size } & $(1.79)$ & $(2.31)$ & $(0.29)$ & $(0.81)$ \\
& $141.87^{\mathrm{c}}$ & $173.37^{\mathrm{a}}$ & $161.37^{\mathrm{b}}$ & $174^{\mathrm{a}}$ \\
& $(2.31)$ & $(1.4)$ & $(1.47)$ & $(3.24)$ \\
\hline
\end{tabular}

${ }^{\mathrm{a}-\mathrm{c}}$ Values with the same superscripts within a row are not statistically different $(P>0.05)$.

${ }^{1}$ CtrlSkim and RCSkim = pasteurized skim milks used in control and reduced-calcium runs, respectively; CtrlUFR and RCUFR are UF retentates obtained from control and reduced-calcium UF runs, respectively.

2008). The presence of higher levels of soluble calcium and phosphate ions in the serum phase of $\mathrm{CO}_{2}$-injected skim milk (RCSkim) and RCUFR as a result of the lower $\mathrm{pH}$ may contribute to disaggregation and internal swelling of the casein micelles, thereby increasing their size. McKenna (2000) also reported an increase in the size of casein micelle as a result of concentration or DF and theorized that this was caused by solubilization of micellar calcium phosphate, which resulted in swelling of the micelle.

\section{Effect of $\mathrm{CO}_{2}$ Injection on UF}

The effect of $\mathrm{CO}_{2}$ injection on the UF process was assessed in terms of flux rates and fouling resistances. Data on initial (Ji) and average (Javg) flux are shown in Table 5. Both Ji and Javg were significantly lower $(P$ $<0.05)$ for RC compared with control. Initial flux was

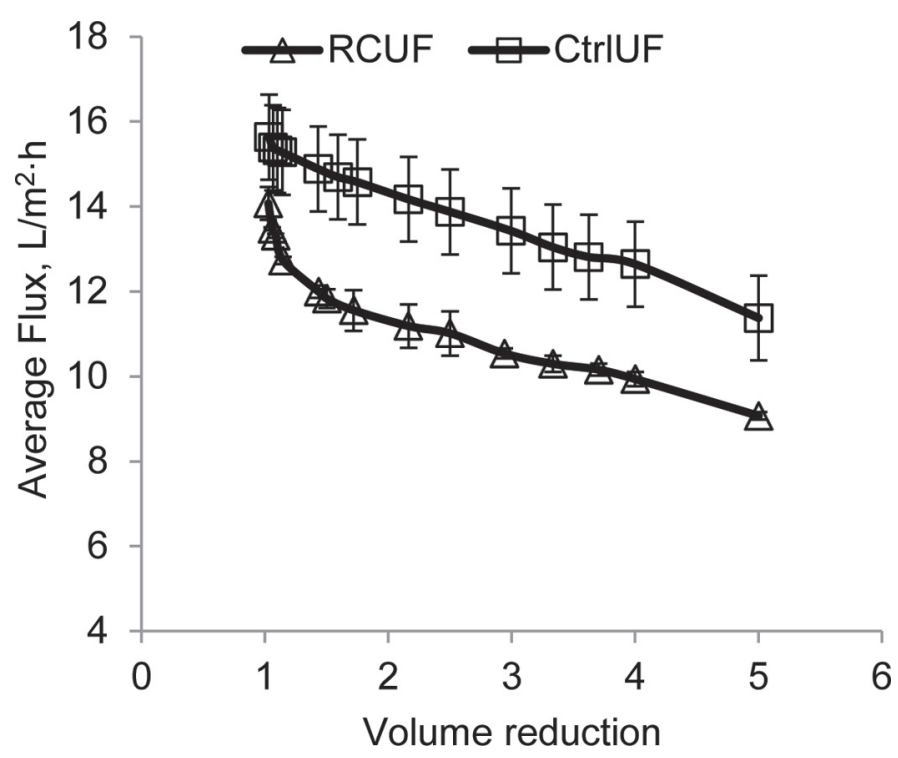

Figure 3. Average flux rates $\left(\mathrm{L} / \mathrm{m}^{2} \cdot \mathrm{h}\right)$ obtained during processing of $189 \mathrm{~L}$ of skim milk into milk protein concentrate with $80 \%$ protein (MPC80) with injection of $\mathrm{CO}_{2}$ (reduced-calcium UF, RCUF) and without injection of $\mathrm{CO}_{2}$ (control UF, CtrlUF). that in the first 2 min of the UF process. The initial flux was about $10 \%$ lower for RC, and Javg was about $20 \%$ lower compared with that of the control. The presence of higher levels of soluble minerals as a result of the lower $\mathrm{pH}$ from the injection of $\mathrm{CO}_{2}$ resulted in significant differences in both Ji and Javg. The Javg obtained at various volume reductions during processing of skim milk into MPC80 with (RCUF) and without (CtrlUF) injection of $\mathrm{CO}_{2}$ are shown in Figure 3. Injection of $\mathrm{CO}_{2}$ into skim milk before and during UF led to about a $10 \%$ reduction in the flux compared with the control at the start of the UF process. The difference in flux increased to $20 \%$ by the time the VR reached 1.4 to 1.5. This difference remained at $20 \%$ for the rest of the process run. By the end of the process, RCUF run had an average flux of $9.07 \mathrm{~L} / \mathrm{m}^{2} \cdot \mathrm{h}$ with a $35 \%$ loss in flux, whereas the CtrlUF run had an average flux of $11.38 \mathrm{~L} /$ $\mathrm{m}^{2} \cdot \mathrm{h}$ with a $27 \%$ loss in average flux.

Data on overall (Rfo) and irreversible (Rfi) fouling resistances are shown in Table 5. Both Rfo and Rfi were significantly higher $(P<0.05)$ for RCUF compared with the CtrlUF run. The Rfo as a function of VR is presented in Figure 4. For RCUF, the Rfo was about 44 $\times 10^{12}$ at the start, and it increased by about $80 \%$ by the end of the process. For CtrlUF process, the Rfo was about $39 \times 10^{12}$ at the start, and it increased by about $58 \%$ by the end of the process. At the start of the UF process, Rfo for RCUF run was about $18 \%$ higher than that of the CtrlUF run, and by the time VR reached

Table 5. Process parameters ${ }^{1}(\mathrm{n}=3$; $\mathrm{SD}$ in parentheses) for reducedcalcium (RCUF) and control (CtrlUF) UF runs

\begin{tabular}{lcccc}
\hline Treatment & Ji & Javg & Rfo & Rfi \\
\hline RCUF & $13.96^{\mathrm{b}}$ & $8.71^{\mathrm{b}}$ & $24.00^{\mathrm{a}}$ & $88.62^{\mathrm{a}}$ \\
& $(0.33)$ & $(0.63)$ & $(4.98)$ & $(9.81)$ \\
CtrlUF & $15.67^{\mathrm{a}}$ & $11.18^{\mathrm{a}}$ & $12.57^{\mathrm{b}}$ & $64.36^{\mathrm{b}}$ \\
& $(0.12)$ & $(0.42)$ & $(3.49)$ & $(3.58)$ \\
\hline
\end{tabular}

${ }^{\mathrm{a}, \mathrm{b}}$ Values with same superscripts within a column are not statistically different $(P>0.05)$.

${ }^{1} \mathrm{Ji}=$ initial flux $\left(\mathrm{L} / \mathrm{m}^{2} \cdot \mathrm{h}\right)$ for the first $2 \mathrm{~min}$; Javg = average flux $(\mathrm{L} /$ $\mathrm{m}^{2} \cdot \mathrm{h}$ ) for the entire run; Rfo (dimensionless, $\times 10^{12}$ ) and Rfi (dimensionless, $\times 10^{12}$ ) $=$ overall and irreversible resistance, respectively. 


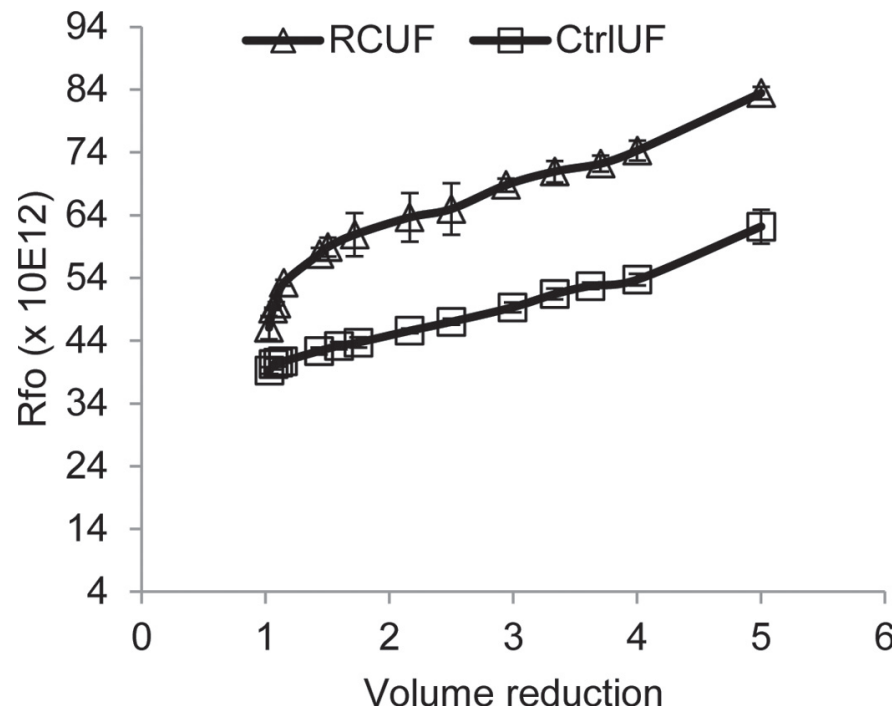

Figure 4. Overall fouling resistances, Rfo (dimensionless, $\times 10^{12}$ ), as a function of volume reduction. Volume reduction was calculated as a ratio of initial volume of the feed (skim milk) and the volume of the retentate at any particular interval of time. $\mathrm{RCUF}=$ reduced-calcium $\mathrm{UF} ; \mathrm{CtrlUF}=$ control UF

1.4, the Rfo difference increased to approximately $35 \%$. Subsequently, the difference remained at 35 to $40 \%$ for the rest of the UF process.

Overall fouling resistance is the sum of reversible and irreversible fouling of the membranes during processing of skim milk into MPC. It includes the effect of concentration polarization (mostly reversible) and fouling due to mineral deposit inside the pores of the UF membranes. The overall fouling resistance for RCUF run was $88.62 \times 10^{12}$, whereas for CtrlUF, overall fouling resistance was about $64.36 \times 10^{12}$. Injection of $\mathrm{CO}_{2}$ before and during UF led to a $38 \%$ increase in the overall fouling resistance. In any membrane processing operation, immediately after the start of the process, the solutes present in the bulk of the fluid accumulate on the surface of the membrane, forming a thin layer of proteins, fat, and other macromolecules. This layer is known as the concentration polarization layer and it becomes the pseudofiltration layer (Marella et al., 2011). Formation of this layer commences after a very short filtration time; this layer is slightly compressible and it densifies as the process proceeds (Bryony et al., 2003). The macromolecules are held in this layer because of interactions among the proteins, minerals, and the membrane. Caseins are the main fouling material in membrane separation processes (Baudry et al., 2005). As seen from the particle size data presented in Table 4, the size of the casein micelle in RCUF was significantly greater than that of CtrlUF. Consequently, in RCUF, the pseudofiltration layer that formed on the membrane should be more porous than that of CtrlUF. This porous layer should, in fact, permeate more material. However, the higher levels of soluble calcium phosphate present in RCUF run caused by the lower $\mathrm{pH}$ from $\mathrm{CO}_{2}$ injection may adversely affect permeation by interacting with the components present in the porous layer. Also, the $\zeta$-potential of casein micelle in $\mathrm{CO}_{2}$-injected skim milk and RCUF retentate was significantly greater than that of control skim milk and CtrlUF retentate (Table 4). When the negative charge ( $\zeta$-potential) on the casein micelles is higher, the electrostatic repulsion between the casein micelles increases. Compared with casein micelles present in CtrlUF retentate, casein micelles present in RCUF retentate have lower $\zeta$-potential, reducing the electrostatic repulsion between the casein micelles. This reduction in $\zeta$-potential may promote casein-casein interactions, contributing to increased fouling resistance. In contrast to Rfo, the irreversible fouling resistance, $\mathrm{Rfi}$, is mainly due to deposition of minerals during skim milk UF. The RCUF run had Rfi of $24 \times$ $10^{12}$, which is about twice that of the CtrlUF runs. The higher levels of soluble calcium phosphate present in the skim milk due to injection of $\mathrm{CO}_{2}$ before and during UF of skim milk led to an increased level of Rfi during the UF process. Calcium phosphate precipitates in the membrane pores, leading to increased irreversible fouling and the resultant decline of UF flux. Calcium phosphate is the predominant salt foulant in milk systems and it affects performance of the membrane process by decreasing the permeation rate. Higher levels of calcium and phosphate may also promote higher levels of membrane-mineral and protein-membrane interactions leading to higher levels of fouling resistances. Free ionic calcium also promotes protein-protein and proteinmembrane interactions, leading to deposition of these materials on membrane surfaces (Rice et al., 2009). The effect of higher levels of minerals present in dairy process streams such as cottage cheese whey and acid whey has been studied and this loss of flux has been attributed to higher levels of calcium and phosphate in the process streams (Hayes et al., 1974; Hickey and Hill, 1980; Hiddink et al., 1981).

\section{Effect of $\mathrm{CO}_{2}$ Injection on Viscosity of UF Retentate}

Viscosity of the UF liquid retentates (17\% solids) was $1.99 \times 10^{-3}$ and $23.6 \times 10^{-3} \mathrm{~Pa} \cdot \mathrm{s}$, respectively, for RCUFR and CtrlUFR. The RCUFR had a lower $(P<$ $0.05)$ viscosity compared with CtrlUFR. We theorize that the higher viscosity of the CtrlUFR was a result of the higher Ca content of the CtrlUFR. We also believe that the lower viscosity of the RCUFR could positively affect the performance of nanofiltration, which is com- 


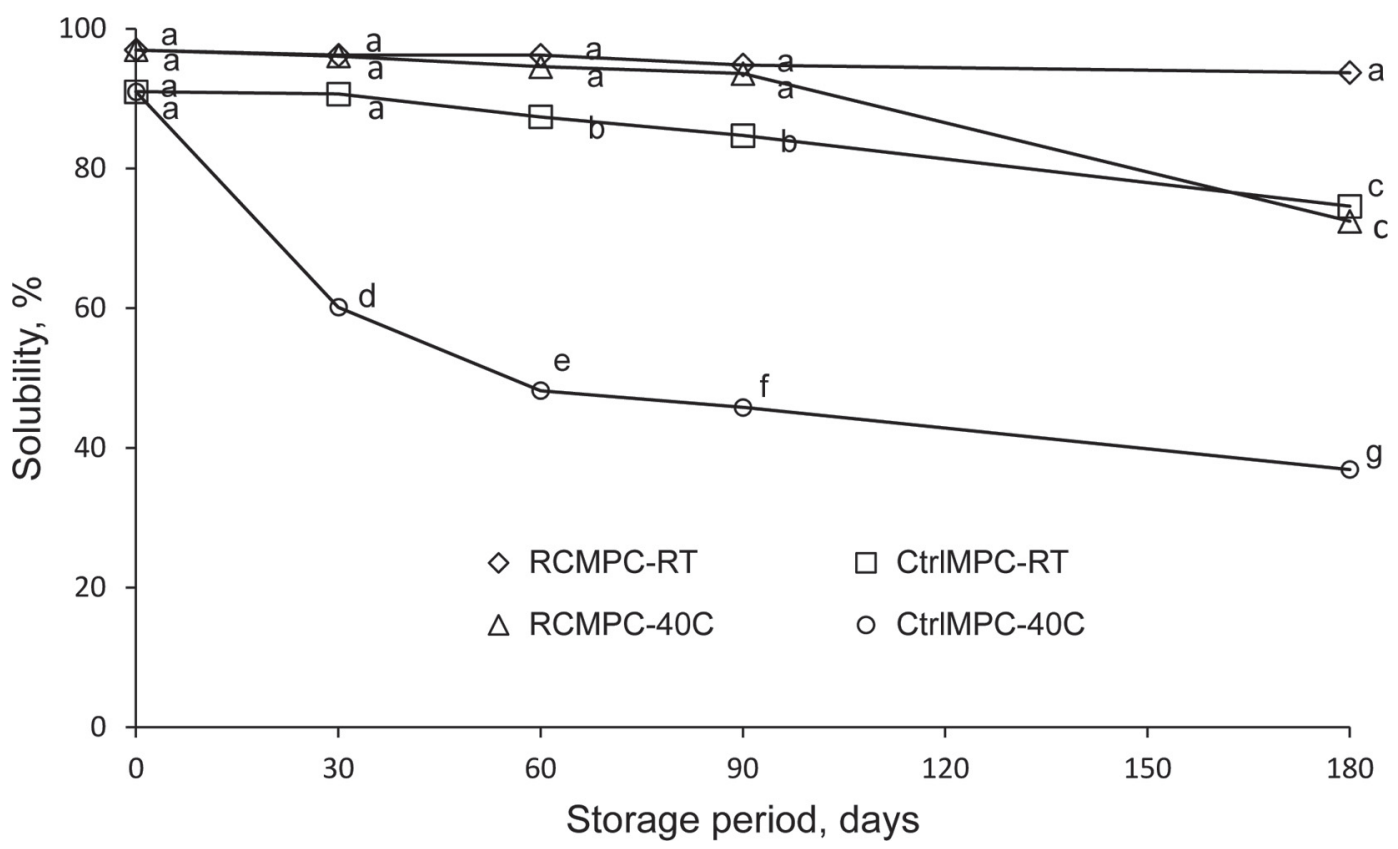

Figure 5. Solubility of milk protein concentrate (MPC) powders as a function of the storage period. RCMPC-RT and CtrlMPC-RT $=$ reduced-calcium and control MPC powders stored at room temperature; RCMPC-40C and CtrlMPC-40C are reduced-calcium and control MPC powders stored at elevated temperature $\left(40^{\circ} \mathrm{C}\right)$. Values with the same letters are not significantly different $(P>0.05)$.

monly used to concentrate UF retentate before spray drying.

\section{Effect of $\mathrm{CO}_{2}$ Injection on Solubility of MPC Stored at Room Temperature}

Solubility is one of the most important functional properties of MPC80. Several studies have shown that MPC80 can lose solubility due to protein-protein and protein-mineral interactions during manufacture and storage. Several studies have reported wide variations in the solubility of commercially produced MPC (de Castro-Morel and Harper, 2002; Sikand et al., 2011). To evaluate the effect of storage period on solubility, the MPC produced in this study was stored at room temperature $\left(22 \pm 1^{\circ} \mathrm{C}\right)$ for $6 \mathrm{mo}$. The solubility during this storage period is shown in Figure 5. The control MPC retained its solubility for $30 \mathrm{~d}$, after which a loss in solubility occurred during storage. By the end of the 180-d storage period, the CtrlMPC solubility was reduced by about $18 \%$. In contrast, the RCMPC did not lose any solubility during storage: solubility at 180 $\mathrm{d}$ of storage was not $(P>0.05)$ different from that at $\mathrm{d}$ 0. It is theorized that storage of MPC results in protein-protein interactions that lead to the formation of insoluble complexes. The nature and extent of formation of these complexes have been studied by several researchers (McKenna, 2000; Havea, 2006; Singh, 2007). The MPC in this study differed in mineral and calcium contents (Table 2). The differences in solubility between the control and RCMPC indicate that calcium and other minerals play a role in the loss of solubility in MPC during storage. Previous research also showed a strong correlation between solubility of MPC and their calcium content (Bhaskar et al., 2007; Sikand et al., 2011, 2013; Ye, 2011).

\section{Effect of $\mathrm{CO}_{2}$ Injection on Solubility of MPC Stored at $40^{\circ} \mathrm{C}$}

To accelerate the protein-protein interactions and calcium-mediated interactions among the proteins, RC$\mathrm{MPC}$ and CtrlMPC were stored at $40^{\circ} \mathrm{C}$ for $180 \mathrm{~d}$; the results are shown in Figure 5. The RCMPC did not lose solubility $(P>0.05)$ for the first $90 \mathrm{~d}$ of storage. However, by $180 \mathrm{~d}$ at $40^{\circ} \mathrm{C}$, a significant $(P<0.05)$ loss in solubility was observed. In contrast, the CtrlMPC lost $(P<0.05)$ solubility by $30 \mathrm{~d}$, and solubility decreased more than $50 \%$ by d 90 .

\section{Cold Solubility}

One of the important properties of any protein ingredient used in drink mixes is its solubility in cold water. To assess the solubility of MPC in cold water, tap water was used to disperse the MPC solutions. As explained in the Materials and Methods section, 5\% protein solutions were made using high-speed stirring 
for 2 min. The RCMPC had a $(P<0.05)$ higher coldwater solubility compared with CtrlMPC (92.15 and $73.63 \%$, respectively). These results indicate that calcium and mineral contents also play an important role in cold solubility of MPC.

\section{CONCLUSIONS}

Carbon dioxide injection before and during UF of skim milk significantly affected ash and calcium contents of MPC80; ash content was reduced by $28 \%$ and $\mathrm{Ca}$ content by $34 \%$. Injection of $\mathrm{CO}_{2}$ resulted in a 2 -fold reduction in the viscosity of the RCUF retentate compared with CtrlUF retentate. The reduction in viscosity may have a beneficial effect during further concentration of UF retentates before drying. However, we observed a $\sim 20 \%$ decrease in flux of RCUF compared with the control, primarily due to solubilization of calcium phosphate. The RCMPC obtained from injection of $\mathrm{CO}_{2}$ retained its solubility when stored at elevated temperature for about $90 \mathrm{~d}$. Our results indicate that $\mathrm{CO}_{2}$ injection can be used to produce MPC80 with reduced calcium and mineral contents and optimal functionality.

\section{ACKNOWLEDGMENTS}

The authors acknowledge Midwest Dairy Food Research Center (Brookings, SD) and Dairy Research Institute (Rosemont, IL) for financial support.

\section{REFERENCES}

Ahmad, S., F. Rousseau, J. F. Gronget, and F. Gaucheron. 2008 Physicochemical characteristics of casein micelles from buffalo milk in different ionic environments: A comparison with cow milk. Milchwissenchaft 63:390-393.

Amamcharla, J. K., and L. E. Metzger. 2011. Development of a rapid method for the measurement of lactose in milk using a blood glucose biosensor. J. Dairy Sci. 94:4800-4809.

Anema, S. G., D. N. Pinder, R. J. Hunter, and Y. Hemar. 2006. Effect of storage temperature on the solubility of milk protein concentrate (MPC 85). Food Hydrocoll. 20:386-393.

Augustin, M. A., P. Sanguansri, R. Williams, and H. Andrews. 2012 High shear treatment of concentrates and drying conditions influence the solubility of milk protein concentrate powders. J. Dairy Res. 79:459-468

Banach, J. C.. S. Clark, and B. P. Lamsal. 2013. Characterization of extruded and toasted milk protein concentrates. J. Food Sci. 78:E861-E867.

Baudry, M. R., G. G. Guiziou, D. R. Calbo, S. Beaulieu, and F. Michel. 2005. Limiting flux in skimmed milk ultrafiltration: Impact of electrostatic repulsion due to casein micelles. Desalination 175:49-59.

Bhaskar, G. V., H. Singh, and N. D. Blazey. 2007. Milk Protein Products and Processes. US Patent 07157108. Assignee: New Zealand Dairy Board.

Bouvier, J. M., M. Collado, D. Gardiner, M. Scott, and P. Schuck 2013. Physical and rehydration properties of milk protein concentrates: Comparison of spray-dried and extrusion-porosified powders. Dairy Sci. Technol. 93:387-399.
Bryony, J. J., J. Yan, and X. D. Chen. 2003. Membrane fouling during filtration of milk-A microstructural study. J. Food Eng. 60:431-437.

Crow, V. L., and F. G. Martley. 1991. An enzymatic assay for $\mathrm{CO}_{2}$ in cheese. J. Dairy Res. 58:521-525.

Dalgleish, D. G., and A. J. R. Law. 1989. pH-Induced dissociation of bovine casein micelles II. Mineral solubilization and its relation to casein release. J. Dairy Res. 56:727-735.

de-Castro-Morel, M., and W. J. Harper. 2002. Basic functionality of milk protein concentrates. Milchwissenschaft 57:367-369.

Dybing, S. T. G. V. Bhaskar, F. P. Dunlop, A. M. Fayerman, and M. J. Whitton. 2007. Modified milk protein concentrates and their use in making gels and dairy products. US Patent \# 07192619. Assignee: New Zealand Dairy Board.

Etzel, M. R., and C. K. Chiu. 1997. Fractionation of lactoperoxidase and lactoferrin from bovine whey using a cation exchange memberane. J. Food Sci. 62:996-1000.

Fyfe, K. N., O. Kravchuk, T. Le, H. C. Deeth, A. V. Nguyen, and B. Bhandari. 2011. Storage induced changes to high protein powders: Influence on surface properties and solubility. J. Sci. Food Agric. 91:2566-2575.

Havea, P. 2006. Protein interactions in milk protein concentrate powders. Int. Dairy J. 16:415-422.

Hayes, J. F., J. A. Dunkerley, L. L. Muller, and A. T. Griffin. 1974. Studies on whey processing by ultrafiltration II. Improving permeation rates by preventing fouling. Aust. J. Dairy Technol. $29: 132-140$.

Helen, J. G., A. S. Grandison, and M. J. Lewis. 2010. The effect of calcium removal from milk on casein micelle stability and structure. Milchwissenschaft 65:151-154.

Hickey, M. W., and R. D. Hill. 1980. Investigations into the ultrafiltration and reverse osmosis of wheys. II. The effect of some minor constituents. NZ J. Dairy Sci. Technol. 15:123-130.

Hiddink, J., R. de Boer, and P. F. C. Nooy. 1981. Effect of various pretreatments on the ultrafiltration of sweet whey at about $55 \mathrm{C}$ Milchwissenchaft. 36:657-663.

Hooi, R., D. M. Barbano, R. L. Bradley, D. Budde, M. Bulthaus, M. Chettiar, J. Lynch, and R. Reddy. 2004. Chapter 15: Chemical and Physical Methods. Pages 480-510 in Standard Methods for the Examination of Dairy Products. 17th ed. H. M. Wehr and J. F. Frank, ed. American Public Health Association, Washington, DC.

Hotchkiss, J. H., B. G. Werner, and E. Y. C. Lee. 2006. Addition of carbon dioxide to dairy products to improve quality: A comprehensive review. Comp. Rev. Food Sci. Food Safety 5:158-168.

Huffman, L. M., and W. J. Harper. 1999. Maximizing the value of milk through separation technologies: Marketing dairy value through technology. J. Dairy Sci. 82:2238-2244.

Huppertz, T., and P. F. Fox. 2006. Effect of $\mathrm{NaCl}$ on some physicochemical properties of bovine milk. Int. Dairy J. 16:1142-1148.

Imtiaz, S. R., B. Kuhn-Sherlock, and M. Campbell. 2012. Effect of dairy protein blends on texture of high protein bars. J. Text. Studies. 43:275-286.

Jimenez-Flores, R., and F. V. Kosikowski. 1986. Properties of ultrafiltered skim milk retentate powders. J. Dairy Sci. 69:329-339.

Kameswaran, S., and D. E. Smith. 1999. Rennet clotting times of skim milk based rennet gels supplemented with ultrafiltered milk protein concentrate. Milchwissenschaft 54:546-549.

King, J. S., and L. A. Mabbitt. 1982. Preservation of raw milk by addition of carbon dioxide. J. Dairy Res. 49:439-447.

Law, A. J. R., and J. Leaver. 1998. Effects of acidification and storage on milk on dissociation of bovine casein micelles. J. Agric. Food Chem. 46:5008-5016.

Law, B. A., and L. A. Mabbitt. 1983. New methods for controlling the spoilage of milk and milk products. Page 131 in Food Microbiology: Advances and Prospects. T. A. Roberts and F. A. Skinner, ed. Acad. Press, London, United Kingdom.

Le, T. T., H. C. Deeth, B. Bhandari, P. F. Alewood, and J. W. Holland. 2012. A proteomic approach to detect lactosylation and other chemical changes in stored milk protein concentrate. Food Chem. 132:655-662 
Ma, Y., and D. M. Barbano. 2003. Milk pH as a function of $\mathrm{CO}_{2}$ concentration, temperature and pressure in a heat exchanger. J. Dairy Sci. 86:3822-3830.

Mao, X. Y., P. S. Tong, S. Gualco, and S. Vink. 2012. Effect of $\mathrm{NaCl}$ addition during diafiltration on the solubility, hydrophobicity, and disulfide bonds of $80 \%$ milk protein concentrate powder. J. Dairy Sci. 95:3481-3488.

Marella, C. 2009. Whey protein fractionation using membrane separation technology. PhD Thesis. South Dakota State University, Brookings, SD.

Marella, C., K. Muthukumarappan, and L. E. Metzger. 2011. Evaluation of commercially available, wide-pore ultrafiltration membranes for production of $\alpha$-lactalbumin-enriched whey protein concentrate. J. Dairy Sci. 94:1165-1175.

McKenna, A. B. 2000. Effect of processing and storage on the reconstitution properties of whole milk and ultrafiltered skim milk powders. PhD Thesis. Massey University, Palmerston North, New Zealand.

Mealy, L., C. Marella, A. C. Biswas, and L. E. Metzger. 2013. Milk mineral harvest from dairy streams using filtration technology. J. Dairy Sci. 96(E-Suppl. 1):85. (Abstr).

Mehra, R., and P. M. Kelley. 2004. Whey protein fractionation using cascade membrane filtration. Bull No. 389. Int. Dairy Federation, Brussels, Belgium.

Muller, A., B. Chaufer, U. Merin, and G. Daufin. 2003. Prepurification of $\alpha$-lactalbumin with Ultrafiltration ceramic membranes from acid casein whey: Study of operating conditions. Lait 83:111-129.

Muthukumarappan, K., and C. Marella. 2010. Membrane processing. Pages 735-830 in Mathematical Modeling of Food Processing. M. M. Farid, ed. CRC Press, Boca Raton, Fl.

Nelson, B. K., J. M. Lynch, and D. M. Barbano. 2004. Impact of milk preacidification with $\mathrm{CO} 2$ on Cheddar cheese composition and yield. J. Dairy Sci. 87:3581-3589.

Patel, R. S., H. Reuter, D. Prokopek, and S. Sachdev. 1991. Manufacture of low lactose powder using ultrafiltration technology. Food Sci. Technol. (Campinas) 24:338-340.
Renner, E., and M. H. Abd El-Salam. 1991. Application of Ultrafiltration in the Dairy Industry. Elsevier Applied Science, New York, NY

Rice, G., A. Barber, A. O'Conner, G. Stevens, and S. Kentish. 2009. Fouling of NF membranes by dairy ultrafiltration permeates. J. Membr. Sci. 330:117-126.

Sikand, V., P. S. Tong, S. Roy, E. Rodriguez-Saona, and B. A. Murray. 2011. Solubility of commercial milk protein concentrates and milk protein isolates. J. Dairy Sci. 94:6194-6202.

Sikand, V., P. S. Tong, and J. Walker. 2013. Effect of adding salt during vbn the diafiltration step of milk protein concentrate powder manufacture on mineral and soluble protein composition. Dairy Sci. Technol. 93:401-413.

Singh, H. 2007. Interactions of milk proteins during the manufacture of milk powders. Lait 87:413-423.

Udabage, P., A. Puvanenthiran, J. A. Yoo, C. Versteeg, and M. A. Augustin. 2012. Modified water solubility of milk protein concentrate powders through the application of static high-pressure treatment. J. Dairy Res. 79:76-83.

Van Hooydonk, A. C. M., H. G. Hagedoorn, and I. J. Boerrigter. 1986 pH-Induced physicochemical changes of casein micelles in milk and their effect on renneting. 1. Effect of acidification on physicochemical properties. Neth. Milk Dairy J. 40:281-296.

Vyas, H. K., and P. S. Tong. 2003. Process for calcium retention during skim milk ultrafiltration. J. Dairy Sci. 86:2761-2766.

Werner, B. G., and J. H. Hotchkiss. 2006. Continuous flow nonthermal $\mathrm{CO}_{2}$ processing: The lethal effects of subcritical and super critical $\mathrm{CO}_{2}$ on total microbial populations and bacterial spores in raw milk. J. Dairy Sci. 89:872-881.

Ye, A. Q. 2011. Functional properties of milk protein concentrates: Emulsifying properties, adsorption and stability of emulsions. Int. Dairy J. 21:14-20. 